\title{
Obraz ponowoczesnego świata z perspektywy współczesnej młodzieży
}

\section{KEYWORDS}

youth, postmodernity, contemporary view of the world, research

\begin{abstract}
Myszka Lucyna, Obraz ponowoczesnego świata z perspektywy współczesnej młodzieży [Image of Postmodern World from the Perspective of Contemporary Youth]. Kultura - Społeczeństwo - Edukacja nr 2(6) 2014, Poznań 2014, pp. 153-173, Adam Mickiewicz University Press. ISBN 978-83-232-2869-1. ISSN 2300-0422

Modern reality is ambivalent, heterogenous, ambiguous and unpredictable. The living conditions it creates aren't easy for adolescing people forced to realize many developmental tasks. Among theese tasks is forming a mature vision of reality. This article presents the postmodern view of the world from the perspective of young people, based on research conducted on high school graduates. It shows young people as very reflective, critical towards certain aspects of postmodernity but at the same time, due to highly developed adaptational skills, able to find their place in the world and make use of its possibilities.
\end{abstract}

Współczesną rzeczywistość zwykło określać się jako nieprzewidywalną, ambiwalentną, trudną do zrozumienia, wieloznaczną, niekonsekwentną, złożoną. Niektórzy obdarzają ją mianem płynnej nowoczesności (Bauman, 2006), kultury instant (Melosik, 2010), McŚwiata (Benjamin, 1997), globalnej wioski (McLuhan, 1962), postmodernizmu. Jednak najbardziej popularnym terminem używanym do określania obecnej rzeczywistości jest ponowoczesność. Z łatwością można się domyślić, że ponowoczesność pojawiła się jako następstwo nowoczesności i jest jej przeciwieństwem. Nowoczesność była określana jako rzeczywistość uporządkowana, kierująca się ściśle zdefiniowanymi regułami, które wyznaczały jej kierunek działania. Pokładała ogromną wiarę w odkryciach naukowych, za pomocą których tłumaczono świat. Z czasem okazało się jednak, że obowiązujące normy przestają być wystarczające, o czym świadczą chociażby wydarzenia mające miejsce w okresie II wojny światowej (zob. Bauman, 2000), co uznano za początek nowej fazy 
życia ludzkości. Jej nazwę stworzono poprzez dodanie przedrostka „po” do słowa „nowoczesność", by w ten sposób podkreślić fakt definitywnego zakończenia tej drugiej (Dziamski, 1995: 147).

Po raz pierwszy słowa „ponowoczesność” w odniesieniu do współczesnej rzeczywistości użył Arnold Toynbee w swoim traktacie Study of History. Później jej analizą zajęli się również inni badacze. Określają ją rozmaicie: jako formę życia, refleksję nad ograniczeniami nowoczesności, kształt egzystencji lub integralną część nowoczesności. Zdaniem Barry’ego Smarta, era ponowoczesności skończyła się w XX wieku i pozostawiła tylko ślad w istniejącej kulturze (Smart, 1998: 12). Z kolei Anthony Giddens twierdzi, że ponowoczesny świat jeszcze nie istnieje i na razie potrafimy tylko uchwycić charakterystyczne dla niego formy funkcjonowania, które odbiegają od tych prezentowanych w rzeczywistości nowoczesnej (Giddens, 2008: 37). Angielski socjolog traktuje ponowoczesność jako przyszłość społeczeństwa, która zaistnieje, gdy ludzie zapomną o nowoczesności. Podaje również pewne cechy ponowoczesności, takie jak: „konsumpcyjna harmonia, powszechna aktywność demokratyczna, demilitaryzacja, a także humanizacja technologii” (Giddens, 2008: 116-117). Zygmunt Bauman postrzega rzeczywistość ponowoczesną jako składową przypadkowych części, które jednak nie stanowią całości, tylko autonomicznie się rozwijają. System, który tworzą, jest niestabilny, nie ma w nim spoistości i równowagi (Bauman, 1991: 10), w związku z czym nie istnieje również żaden koherentny system wartości, który jednostka mogłaby przyjąć za własny (Matysek, 2007: 26). „Zamiast trwałych i stabilnych hierarchii oraz wyraźnych linii ewolucyjnych mamy nieustanne starcia sprzecznych opinii i sądów (...) oraz bitwy prowadzące w najlepszym razie do stworzenia nowych hierarchii równie kruchych, nietrwałych i tymczasowych jak poprzednie" (Bauman, 2011: 243).

Ponowoczesność stanowi zatem bardzo złożone zjawisko, będące konsekwencją wcześniejszej epoki, która ujawnia w niej swoje wady i niedoskonałości. Nie tylko nie sposób jej zdefiniować ze względu na mnogość aspektów, których dotyczy, ale także trudno określić jej ramy czasowe. Według niektórych badaczy, ponowoczesność stanowi rzeczywistość aktualnie przeżywaną, ale pojawiają się również głosy, że ma ona dopiero nastąpić. Fakt ten sprawia, że problem jest interesujący i zachęca do pogłębionej refleksji. Nieprzewidywalna i niełatwa do zrozumienia rzeczywistość kryje w sobie niezgłębioną tajemnicę. Ze względu na swoją złożoność staje się trudnym przedmiotem egzemplifikacji badawczych, dlatego też poświęcane jej publikacje mają często charakter teoretyczny. Dyskursy poruszające zagadnienia związane z ponowoczesnością oscylują wokół wybranych aspektów ją dookreślających. 
Nie sposób analizować współczesnego świata bez przyjrzenia się kondycji żyjącego w nim człowieka. Jedną z podstawowych potrzeb jednostki ludzkiej jest poczucie bezpieczeństwa (zob. Maslow, 1987), możliwe do osiągnięcia w warunkach względnej stałości i znajomości otoczenia. W związku z tym rodzi się pytanie: czy ponowoczesność zapewnia człowiekowi bezpieczeństwo? Permanentna zmienność i ambiwalencja wymaga rozwinięcia umiejętności adaptacji i elastyczności na bardzo wysokim poziomie. Dlatego też można pokusić się o stwierdzenie, że właśnie owa niestałość, balansowanie pomiędzy różnymi płaszczyznami, stanowi dla jednostki pewien punkt odniesienia i stabilizacji. Tak naprawdę to, w jaki sposób jednostka poradzi sobie w warunkach oferowanych przez ponowoczesność, w dużej mierze uzależnione jest od posiadanych predyspozycji psychologicznych, świadczących o jakości ukształtowanej orientacji prorozwojowej (zob. Cybal-Michalska, 2006). Umiejętność permanentnego aktualizowania swoich możliwości przez jednostkę ma kluczowe znaczenie dla rangi odnoszonego przez nią sukcesu życiowego. W związku z tym jej zainteresowanie powinno się koncentrować na psychologiczno-społecznych determinantach prorozwojowych, wśród których ogromne znaczenie ma motywacja wewnętrzna, poczucie sprawstwa oraz pozytywne nastawienie w kierunku przyszłości.

Współczesnego człowieka można z jednej strony scharakteryzować jako osobę poddającą się oddziaływaniom istniejącej rzeczywistości, a za atrybuty jego życia uznać „niespójność, niekonsekwencję postępowania, fragmentaryzację i epizodyczność rozmaitych sfer aktywności” (Bauman, 1993: 7). Jednak z drugiej strony, podobne cechy, świadczące o konformizmie i bierności wobec ponowoczesności, można uznać za jego siłę i świadectwo zaradności. Obecny świat w dużej mierze jest kreowany przez człowieka, i pomimo tego, że w pewnym sensie niejednokrotnie traci on nad nim panowanie - świat stanowi płaszczyznę jego życia. Jednostka przyjmuje w nim różne postawy: włóczęgi, spacerowicza, turysty czy gracza (zob. Bauman, 1993), lub przejawia zachowania charakterystyczne dla tożsamości globalnej, upozorowanej, typu: supermarket, amerykańskiego lub brzytwy (zob. Melosik, 1998). Oczywiście, posiada również prawo do tego, by samodzielnie kreować swój wizerunek lub reprezentować różne style funkcjonowania. Ponowoczesność stwarza szerokie pole możliwości krystalizowania tożsamości. Istotę stanowi umiejętność udzielenia odpowiedzi na jedno z podstawowych pytań egzystencjalnych „kim jestem?”, „kim się staję?”.

Kondycja człowieka nie jest wolna od determinującego wpływu jakości współczesnego społeczeństwa. W literaturze można napotkać różnego rodzaju terminy 
służące dookreśleniu tego ostatniego. Definicyjne credo najczęściej uwzględnia dodawanie przedrostków „po”, „post”, „późne”. Karl Popper nadaje mu miano „społeczeństwa otwartego" (Popper, 1993). Charakteryzuje się ono brakiem harmonii i niepewnością. Kreowane jest poprzez zbiór indywidualnych jednostek, mających prawo do wolności i posiadania własnego światopoglądu (Popper, 1993: 223-224). Z kolei Jean Baudrillard nazywa je „społeczeństwem konsumpcyjnym”, a za dominującą ideę uznaje posiadanie jak największej ilości dóbr i towarów, których chęć nabycia jest wiecznie niezaspokojona i nieustannie pobudzana przez perspektywę osiągnięcia nowych możliwości. Dlatego też znaczenie ludzi jest obecnie uzależnione od ich majątku (Baurdillard, 2006). Inny myśliciel, Manuel Castells, jest propagatorem koncepcji „społeczeństwa sieci”, istniejącego dzięki rozwojowi przemysłu informatycznego i mediów, za pośrednictwem których tworzy się sieć relacji międzyludzkich (Castells, 2007). Podobna do powyżzzej jest idea „społeczeństwa informacyjnego”, której twórcą jest Tadao Umesao (1963), zaś jej późniejszy propagator, John Naisbitt, podkreśla, że istotę funkcjonowania zbiorowości ludzkich stanowi tu informacja, a dostęp do niej gwarantuje ich istnienie (Naisbitt, 2003). Ulrich Beck nazywa współczesne społeczeństwo „społeczeństwem ryzyka”, gdyż zagrożone jest ono różnego rodzaju niebezpieczeństwami, takimi jak katastrofy ekologiczne, społeczne, informatyczne, które są wywołane nie tylko przez czynniki zewnętrzne, ale również poprzez działanie człowieka (Beck, 2002). Daniel Bell (1999) ukuł pojęcie „społeczeństwa postindustrialnego”, którego głównym wyznacznikiem jest jakość życia, natomiast Alvin Toffler (2001) nadał mu miano „społeczeństwa trzeciej fali” - nastawionego na tworzenie nowej wiedzy i kwestionowanie istniejących reguł. Marek Kwiek rozpatruje współczesne społeczeństwo z perspektywy wspólnoty ponadnarodowej, tworzonej przez mieszkańców całego globu, pomiędzy którymi zacierają się różnice regionalne, i nazywa je „społeczeństwem po-narodowym” (Kwiek, 2000).

Mnogość terminów używanych na określenie współczesnego społeczeństwa świadczy o tym, że prezentuje ono różne oblicza, które nie wykluczają się wzajemnie, ale są względem siebie komplementarne. Społeczeństwo poddawane jest ciągłym zmianom, natomiast jakość jego przeobrażeń może dookreślić permanentna fluktuacja. Stałą jego właściwość stanowi rozwój, a jego konsekwencją jest wszechobecne ryzyko dotyczące niemalże wszystkich sfer egzystencji człowieka.

W obliczu powyższych rozważań, warto zadać sobie pytanie, jak będzie wyglądało społeczeństwo przyszłości i w jakim kierunku zmierza ów rozwój? Ponowoczesną rzeczywistość często określa się jako świat „końców” (Kwieciński, 2004: 
203) lub „kryzysów” (Kargulowa, 2004: 163-167). Początki nowej epoki zawsze wiążą się z zakończeniem zjawisk charakterystycznych dla czasów wcześniejszych i wykształceniem się innej, nowej jakości. To, co nowe i nieznane, zawsze budzi lęk oraz pewne obawy. Partycypując w rzeczywistości ponowoczesnej, można zastanowić się nad tym, w jakich kierunkach będzie podążał globalizujący się świat.

Niestety, antycypacja tego, jaki będzie świat przyszłości, jest trudna do uchwycenia. Potwierdzają to słowa laureatki Nagrody Nobla, Iliji Prigogine, traktujące o tym, że „nie możemy przewidzieć przyszłości, ale możemy się na nią przygotować" (Prigogine, 1994). Wypowiedź ta zawiera bardzo dużo racji, a jednocześnie pociąga człowieka do dużej odpowiedzialności nie tylko za siebie, ale również za przyszłość pokoleń. Oznacza to, że każde swoje działanie należy poddawać krytycznej ocenie i starać się przewidzieć jego skutki, w związku z czym funkcjonowanie ludzi powinno opierać się na refleksyjnej prewencji i antycypacji przyszłych wydarzeń (Mayor, 2001: 485). Staje się to ich moralnym obowiązkiem ze względu na swój własny los.

Młodzież zmuszona jest do funkcjonowania we współczesnej rzeczywistości. Osoby przeżywające okres dojrzewania poszukują nie tylko swojego miejsca w świecie, ale również kształtują poglądy na jego temat. Jednym z zadań rozwojowych (zob. Havighurst, 1981; za: Oleszkiewicz 1995: 72) przypadających na okres dojrzewania jest ukształtowanie własnego stosunku do świata, systemu wartości oraz opanowanie umiejętności funkcjonowania w życiu społecznym - zadania te nie mają już tylko charakteru odtwórczego, jak w przypadku socjalizacji pierwotnej, ale skupiają się również na krytycznym rozumieniu zachodzących sytuacji. Co więcej, w obliczu kultury prefiguratywnej, z którą mamy do czynienia we współczesnych czasach, młodzież zmuszona jest nie tylko sama nabywać nowe umiejętności, ale również przekazywać je swoim rodzicom, nieradzącym sobie ze zmianami (Mead, 2000: 23). Dlatego też młodzi ludzie powinni wykazać się ogromną czujnością, aby każde z napotykanych przeobrażeń potraktować jako szansę na rozwój i wykorzystać w najbardziej konstruktywny dla siebie sposób.

Dziecko często reprezentuje fragmentaryczny i bardzo zmienny „światopogląd naiwny" (Obuchowska, 1983: 69), natomiast nastolatek stoi przed zadaniem nabycia przekonań o świecie opartych o własne przemyślenia. Nie powinien przejmować ich konformistycznie od poprzednich generacji, których reprezentantami najczęściej są rodzice, ale samodzielnie konstruować je w odniesieniu do istniejącej rzeczywistości. Zdobyte w ten sposób wyobrażenia odgrywają doniosłą rolę w życiu jednostki - pozwalają jej na wyznaczanie sobie ukierunkowanych dążeń, sta- 
nowią podstawę oceny swojego postępowania oraz zachowań innych ludzi, zapewniają poczucie harmonii, a także zrozumienie świata (Reykowski, 1958). Można nawet pokusić się o konkluzję, że światopogląd pomaga w odnalezieniu sensu życia. Ukształtowana struktura wyobrażenia rzeczywistości pozwala na wygenerowanie celu swojego istnienia. Okazuje się, że młode jednostki tworzą go na podstawie wizji swojej przyszłości (Bakiera, 2009: 104).

Każdy człowiek posiada własne wyobrażenie na temat istniejącej rzeczywistości. Jest ono uwarunkowane nie tylko powszechnie panującymi przekonaniami, ale również indywidualnie przeżywanymi doświadczeniami. Głębsze analizy pokazują, że stworzenie jednoznacznego i kompletnego wizerunku obecnego świata staje się niemal niemożliwe, ponieważ kryje on w sobie różne oblicza i poddawany jest nieustannym zmianom. Co więcej, trudno określić go jednym sformułowaniem, chociażby $\mathrm{z}$ tego względu, że każda jednostka posiada prawo do obdarzania go wybranymi epitetami, podobnie jak badacze mogą nadawać mu różnorodne przymioty, koncentrując się na różnych jego aspektach.

Współczesna rzeczywistość, pomimo tego, że niesie ze sobą bardzo wiele niebezpieczeństw, stanowi również optimum szans dla dojrzewającej jednostki, która posiada zdolność do samodzielnego kreowania swojego wizerunku, jak również kształtowania na tej podstawie swojego poglądu na świat.

Badania, na podstawie których zrekonstruowano obraz ponowoczesnej rzeczywistości z perspektywy adolescentów, przeprowadzono na przełomie grudnia 2012 roku i stycznia 2013 roku na terenie województwa wielkopolskiego oraz kujawsko-pomorskiego w pięciu wybranych szkołach ponadgimnazjalnych, wyselekcjonowanych ze względu na swoją lokalizację i dostępność, ponieważ nie wszyscy dyrektorzy szkół wyrazili zgodę na przeprowadzenie eksploracji badawczych. Badania poświęcone były przede wszystkim autoidentyfikacjom młodych ludzi $\mathrm{w}$ dobie ponowoczesności, jednak na postawie pytań zawartych w kwestionariuszu ankiety, którym się posłużono, można również udzielić odpowiedzi na pytanie: „jaki jest obraz ponowoczesnego świata z perspektywy młodzieży?”'.

Badaniami objęto łącznie 173 uczniów uczęszczających do ostatnich klas szkół ponadgimnazjalych. Były to osoby w wieku od 18 do 20 lat. Młodszym wiekiem charakteryzowali się przyszli absolwenci szkół zawodowych i liceów ogólnokształcących, natomiast starszym - ze względu na dłuższy okres pobytu w instytucjach

\footnotetext{
${ }^{1}$ Przytoczone rozważania stanowią fragment dociekań naukowych i eksploracji badawczych poczynionych przez autorkę w pracy naukowej pt. Autoidentyfikacje młodzieży w dobie ponowoczesności napisanej pod kierunkiem prof. UAM dr hab. Agnieszki Cybal-Michalskiej.
} 
kształcenia - uczniowie techników. Uwagę na tę grupę wychowanków zwrócono z powodu osiągnięcia przez nich wieku, w którym powinni odznaczać się relatywnie ustabilizowanym światopoglądem i stosunkiem do współczesnej rzeczywistości².

Sposób postrzegania świata przez badaną młodzież pozwala wnioskować o jej stosunku do rzeczywistości oraz o tym, jak się w niej odnajduje. Obraz stworzony przez adolescentów jest bardzo złożony, co czyni go niezwykle interesującym. Przedstawia ciekawą poznawczo interpretację ponowoczesności oraz ukazuje szerokie spektrum wiedzy o młodych ludziach i ich sposobie myślenia oraz umiejętności odczytywania znaczeń. Świat, w którym zmuszeni są funkcjonować, zostaje przez nich postrzegany raczej w kategoriach negatywnych (aż 70\% skojarzeń dotyczących współczesności zakwalifikowano jako niepozytywne). Zjawisko to świadczy o bardzo krytycznym podejściu do przestrzeni swojego życia oraz przyjmowaniu pewnego rodzaju postawy buntowniczej (zob. Oleszkiewicz, 2006), charakterystycznej dla okresu dojrzewania.

Wniosek taki wysnuto na podstawie skojarzeń respondentów dotyczących ponowoczesnego świata, które skategoryzowano $\mathrm{w}$ trzech grupach: pozytywnych, negatywnych i neutralnych. Z powodu stworzenia licznego zbioru określeń współczesności, zajęto się szczegółową analizą epitetów podawanych na trzech kolejnych pozycjach. Okazało się, że tylko $15,6 \%$ ankietowanych w pierwszym wskazaniu postrzega współczesny świat w kategoriach pozytywnych; dane wykazują niewielką tendencję rosnącą w przypadku następnych skojarzeń (16,7\% w drugim wskazaniu i 18,5\% w trzecim wskazaniu). Odsetek określeń neutralnych stanowił odpowiednio: $13,9 \% \mathrm{w}$ pierwszym wskazaniu, $7,5 \% \mathrm{w}$ drugim wskazaniu i $11,5 \% \mathrm{w}$ trzecim wskazaniu.

Współczesny świat, postrzegany przede wszystkim w kategoriach negatywnych, jawi się jako „niesprawiedliwy” (13,9\%), „zakłamany” (13,3\%), „zły” (9,8\%), „fałszywy” (9,2\%), „brudny” (8,1\%), „okrutny” (7,5\%), „dążący do samozagłady”, „podzielony na lepszych i gorszych”. Stworzenie tak licznej grupy nieprzyjemnych określeń świadczy o ogromnych trudnościach egzystencjalnych, jakich doświadcza młodzież. Funkcjonowanie w rzeczywistości zmierzającej do samozatracenia jest

${ }^{2}$ Grupa badanych była bardzo zróżnicowana. Łącznie ankietę wypełniły 173 osoby, kobiety stanowiły $42,8 \%$, natomiast płeć męską reprezentowało $57,2 \%$ ogółu ankietowanych. W tym można wyróżnić: 22,5\% uczniów szkół zawodowych, 49,2\% uczniów techników i 28,3\% osób uczęszczających do liceów. Natomiast jeśli chodzi o rozkład badanych względem miejsca zamieszkania, okazuje się, że $58,4 \%$ respondentów pochodzi z terenów wiejskich, 7,5\% zamieszkuje miasta nieprzekraczające 50 tysięcy mieszkańców, 5,8\% miasta, których liczba mieszkańców plasuje się w przedziale 50-100 tysięcy, zaś 28,3\% pochodzi z wielkich aglomeracji miejskich liczących powyżej 100 tysięcy mieszkańców. 
wręcz niemożliwe. Obraz ponowoczesności jawi się młodym ludziom jako pełen zagrożeń i niezadowalający. Niecały procent badanych $(0,6 \%)$ scharakteryzował ją wyłącznie w kategoriach pozytywnych. Do najczęściej pojawiających się określeń dotyczących tej kategorii skojarzeń na temat współczesnego świata należą takie, jak: „nowoczesny” (19,1\%), „ciekawy” (9,2\%), „piękny” (7,5\%). W grupie pozytywnych epitetów znalazły się również takie przymiotniki, jak: „rozwinięty”, „pracowity”, „wygodny”, „cywilizowany”, „dobry”, „rozbudowany”, „innowacyjny”, „cudowny”, „radosny”, „pełen możliwości”, „otwarty”. Z kolei do zbioru nazw neutralnych zaliczano takie, jak: „inny”, „skomputeryzowany” (11,0\%), „zmieniający się”, „wielokulturowy”, „dziwny” (9,2\%), „zaskakujący”, „tajemniczy”, „różnorodny”, „wielki”.

Interesującym z perspektywy swojej złożoności zjawiskiem jest fakt, że teraźniejszość zostaje odczytywana przez młodzież jako pełna sprzeczności. Potrafi być jednocześnie „nudna” i „ciekawa”, „biedna” i „bogata”, „wsteczna” i „rozwinięta”, „pełna możliwości” i „zmierzająca ku zagładzie”. Sytuacja ta wskazuje na fragmentaryczność wielu zjawisk, które nie tylko w całości można odbierać różnie, ale także odmiennie interpretować ich poszczególne składowe. Można nawet pokusić się o stwierdzenie, że wyobrażania adolescentów odzwierciedla charakter ponowoczesności. Badani podkreślali jej nieprzewidywalność i wieloaspektowość, a także możliwość prezentowania się $\mathrm{w}$ skrajnych postaciach, w zależności od aktualnie rozpatrywanej płaszczyzny. Świadczy to o ich dojrzałym sposobie spostrzegania obecnych czasów, ponieważ zdają sobie sprawę z tego, że właściwości i specyfika ponowoczesnych realiów może być różnorodna, a nie wyłącznie jednorodna. Ponadto, własnym przykładem badani udowadniają, że do tak skomplikowanych warunków, jakie stwarza dzisiejszy świat, można się przystosować. Co więcej, odnajdują w nim szereg wartości, z których czynią podstawę własnych identyfikacji.

Wyniki badań wskazują na istnienie pewnego paradoksu myślowego wśród młodych ludzi. Polega on na tym, że oceniają oni świat w kategoriach bardzo negatywnych oraz wróżą jego bliską zagładę, jednak snują dalekosiężne i bardzo optymistyczne plany przyszłościowe oraz, co ważniejsze, we wszystkich z nich bazują na zasobach i możliwościach oferowanych przez ponowoczesność. Tendencję taką można wyjaśnić, odnosząc się do interesującego stwierdzenia Zdzisława Kosyrza, który utrzymuje, że postrzeganie współczesnego świata jako dualistycznego wcale nie oznacza sprzeczności w jego odbiorze, ale stanowi wynik głębokich przemyśleń, które w konsekwencji bazują na wniosku, że właściwości sprzeczne są ze sobą tak silnie powiązane, że stanowią swoje kontinuum (Kosyrz, 2012: 16-17). Stwier- 
dzenie to pozwala zrozumieć, dlaczego młodzież wyraźnie ocenia ponowoczesność jako pełną sprzeczności.

Zbiór skojarzeń na temat ponowoczesności stworzony przez przyszłych absolwentów szkół ponadgimnazjalnych można interpretować nie tylko jako odzwierciedlenie subiektywnych przekonań z nią związanych, ale także jako swoisty sposób autoidentyfikacji, wpływający na poczucie bycia sobą, ponieważ często to, za kogo siebie uważamy, zależne jest od otoczenia, w którym funkcjonujemy. Zgodnie ze stwierdzeniem Kazimierza Obuchowskiego, „spostrzegamy świat w sposób zmodyfikowany przez nasze oczekiwania, dopatrując się w nim tego, co jest w istocie w nas, i odwrotnie, pewne stany świata zewnętrznego traktujemy tak, jakby były naszymi stanami" (Obuchowski, 2000: 135). W myśl niniejszego założenia, jednostka w pełni utożsamia się ze sobą dopiero wówczas, gdy oddzieli Ja od tego, co nim nie jest, dzięki czemu uzyska łączność z otaczającą ją rzeczywistością i stanie się za nią odpowiedzialna. Taka postawa przyjęta przez młodych ludzi może świadczyć o stawianiu przez nich oporu wobec niektórych atrybutów ponowoczesności, które, $\mathrm{z}$ ich punktu widzenia, są istotne i wymagają naprawy. Na podstawie udzielonych odpowiedzi można wywnioskować, że należą do nich czynniki służące do kategoryzacji jednostek, takie jak zamożność, miejsce urodzenia, władza, obecny kryzys gospodarczy, szybkie tempo życia i zakłamanie.

Podział uzyskanych wyników ze względu na wybrane zmienne, do których należy między innymi płeć, dowodzi, że mężczyźni częściej spostrzegają współczesność w kategoriach pozytywnych w przypadku wszystkich trzech wskazań, jak również przejawiają do niej stosunek bardziej neutralny. Z kolei kobiety prezentują zdecydowanie bardziej negatywną postawę względem ponowoczesności. Okazuje się również, że uczniowie technikum interpretują współczesność najbardziej neutralnie, licealiści negatywnie, zaś przyszli absolwenci szkół zawodowych odnoszą się do niej w sposób najbardziej pozytywny. Co więcej, licealiści używają najbardziej urozmaiconego słownictwa, tworząc bogaty zbiór skojarzeń. Ciekawym spostrzeżeniem jest także fakt, że zmienna miejsce zamieszkania różnicuje obraz ponowoczesności. Mieszkańcy wsi definiują ją jako „zabieganą” (17,8\%), „złą” (13,9\%), „okrutną" $(8,9 \%)$ oraz „podzieloną na lepszych i gorszych”. Uczniowie $\mathrm{z}$ wielkich aglomeracji miejskich przypisują jej głównie takie cechy, jak: „niesprawiedliwa” (22,4\%), „szybka” $(20,4 \%)$ oraz „brudna” (12,2\%). Prawidłowość ta ukazuje, że miejsce pochodzenia warunkuje zbiór aspektów, do których przywiązuje się uwagę. Mieszkańcy małych miejscowości czują się bardziej przytłoczeniu szybkim tempem życia i podziałami społecznymi, których często ofiarami się stają, nato- 
miast osoby zamieszkujące miasta $\mathrm{w}$ większym stopniu dostrzegają nieporządek panujący w swoim otoczeniu.

Analiza dostępnych w literaturze egzemplifikacji badawczych na temat młodzieży ukazuje bardzo podobny do opisanego powyżej obraz nastolatków. Zgodnie z rezultatami dociekań Hanny Świdy-Ziemby (2005: 35-38), postrzegają oni obecną rzeczywistość w kategoriach bardzo krytycznych. Uważają, że współczesny świat jest źródłem wielu możliwości i można w nim odnaleźć zadowolenie, jednak występuje w nim zbyt mało aktywności kulturalnych związanych z obcowaniem ze sztuką, historią i muzyką. Badania pozwoliły również na wyłonienie grupy młodzieży niezadowolonej, cynicznej, narzekającej na powszechną żądzę pieniądza i powierzchowność kontaktów interpersonalnych. Zadaniem autorki, takie różnice w postrzeganiu świata są zależne od uznawanych wartości, światopoglądu oraz poczucia sensu życia.

Heterogeniczna gramatyka ponowoczesności przyczynia się do wielorakiego jej interpretowania. Każdy z jej uczestników zwraca uwagę na inne aspekty. Sytuacja taka spowodowana jest tym, że złożoność współczesności nie pozwala na jej całkowite zrozumienie. Co więcej, różnorodność jej odbioru nie oznacza również, że któraś z metod jej postrzegania staje się niewłaściwa, ponieważ każda jednostka ma prawo do przypisania istotności innemu wymiarowi. Chcąc dowiedzieć się, który ze sposobów jej określania jest najbardziej uznawany przez przyszłych absolwentów szkół ponadgimnazjalnych, poproszono ich o wybór jednego z podanych twierdzeń. Niektóre z nich skonstruowano na podstawie definicji współczesnej rzeczywistości stworzonych przez interesujących się nią badaczy.

Młodzież utożsamia najczęściej pojęcie ponowoczesności z przemianami cywilizacyjnymi, wiążącymi się ze zmianą stylów funkcjonowania i zachowywania się ludzi $(31,2 \%)$. W taki sposób w swoich pracach tłumaczył ją wybitny badacz tej epoki - Zygmunt Bauman (zob. Bauman, 2007). Można na tej podstawie stwierdzić, że interpretacja tego autora pozostaje najbliższa młodym jednostkom, które zauważają, że współczesny człowiek zaczyna przejawiać coraz bardziej różnorodną gamę zachowań. Młodzi ludzie obserwują pojawianie się form, które wcześniej, nawet $\mathrm{w}$ ich krótkim okresie życia, były niespotykane albo nie mieściły się $\mathrm{w}$ obszarze społecznie akceptowanych, natomiast obecnie występują na porządku dziennym. Podobne przekonania mogą kształtować się również na podstawie informacji uzyskiwanych od starszych pokoleń, w tym głównie od rodziców, którzy opowiadają im o życiu z czasów swojej młodości. Analiza danych ze względu na zmienne ukazuje, że kobiety prawie dwukrotnie częściej niż mężczyźni wiążą poję- 
cie ponowoczesności z przemianami cywilizacyjnymi i zmianami zachowań ludzi (kobiety - 43,2\%, mężczyźni - 22,2\%).

Inną, także często wybieraną przez respondentów opcją było określenie umiejscawiające ponowoczesność w obszarze światopoglądowym, związanym z pojawianiem się nowych sposobów myślenia o rzeczywistości (28,9\%). Propozycję takiego jej rozumienia odnaleźć można w jednej z pozycji Anny Zeidler-Janiszewskiej (1995). Sytuacja taka świadczy o spostrzeżeniu przez adolescentów pewnej prawidłowości, zgodnie z którą środowisko egzystowania jednostki zawsze w pewien sposób kształtuje jej sposób patrzenia na świat. Obecne czasy także narzucają określoną ideologię, która wpływa na formułowanie się pewnych postaw. Te zaś z kolei w dużej mierze decydują o zachowaniu człowieka.

Wiele osób zauważa również, że współczesna rzeczywistość przyczynia się do zerwania z wszelkimi dotychczasowymi normami, wartościami i tradycjami uznawanymi przez wcześniejsze pokolenia (10,4\%). Jest to bardzo powszechna opinia, niejednokrotnie wyrażana przez wielu ludzi. Często można spotkać się ze stanowiskami głoszącymi hasła o zdemoralizowanym społeczeństwie pozbawionym uniwersalnych reguł. W takim przypadku rodzi się pytanie o to, czy osoby zgadzające się $\mathrm{z}$ powyższym sformułowaniem same stanowią grupę postępującą zgodnie $\mathrm{z}$ jego myślą, czy też się z niej wykluczają? Jednostka zaznajomiona $\mathrm{z}$ kanonem wartości może bowiem dostrzegać zanik ich uznawania zarówno u siebie, jak i u innych. Sytuację taką należy interpretować także jako powstawanie nowych, bardziej elastycznych reguł, dostosowanych zarówno do zmiennej, jak i fragmentarycznej rzeczywistości.

Ze stwierdzeniem Anthony’ego Giddensa (2008), wskazującym na oddziaływanie ponowoczesności w sferze kulturalnej, co wyraża się w pojawianiu się nowych nurtów w literaturze i sztuce, zgadza się 9,8\% badanych. Powyższe prawidłowości zawsze towarzyszą każdej nowej epoce. Bez trudu można zauważyć, że styl pisania czy choćby wysławiania się starożytnych odbiega od tego, który obowiązywał w średniowieczu. Podobna właściwość zachodzi w architekturze, ponieważ współczesne budowle zdecydowanie różnią się od tych, które powstawały w czasach baroku. Dostrzeganie tego faktu może dowodzić orientacji młodych ludzi również na tej płaszczyźnie.

Kwintesencją wszystkich przytoczonych definicji ponowoczesności jest sformułowanie traktujące o tym, że stanowi ona przeciwieństwo nowoczesności, po której następuje. Popiera je 9,8\% ankietowanych. Wyjaśnienie to przyjmuje postać bardzo ogólną i zawiera w sobie praktycznie wszystkie pozostałe, ponieważ skoro 
współczesną rzeczywistość utożsamia się z samymi zmianami i przeobrażeniami $\mathrm{w}$ różnych sferach, to w konsekwencji musi charakteryzować się ona odmiennością w porównaniu do czasów minionych - inaczej byłaby ich kontynuacją, więc trwałyby nadal. Stosunkowo rzadki wybór tego wariantu wskazuje na to, że adolescenci wolą postrzegać obecne czasy w odrębnych kategoriach.

Najrzadziej wybieraną przez młodzież opcją było rozumienie ponowoczesności jako zerwania $\mathrm{z}$ monopolem wielkich mocarstw, takich jak Stany Zjednoczone i kraje europejskie, i ustaniem ich przywództwa na płaszczyźnie ekonomicznej, politycznej i kulturalnej (6,9\%). Zjawisko takie można interpretować dwojako, albo jako powszechnie utrzymujące się przekonanie o tym, że sytuacja taka nadal ma miejsce i światem zarządzają najbardziej zamożne państwa, albo jako brak tendencji młodych ludzi do interesowania się tą płaszczyzną lub nieuznawanie jej za istotną w odniesieniu do ponowoczesności.

Niewielka liczba badanych podjęła się także próby samodzielnego skonstruowania odpowiedzi na pytanie o to, jak rozumieją ponowoczesność (3,0\%). Można wśród nich odnaleźć następujące propozycje: „Ponowoczesność stanowi pogłębiające się stadium upadku ludzkiego, trzebionego przez bezsensowne wojny oraz dbanie tylko o własne interesy”; „Ponowoczesność wskazuje na ciągłe powstawanie czegoś nowego”; „Ponowoczesność powoduje zniszczenie za przyczyną pojawiających się nowych słabości”. Definicje te tworzone są poprzez wymienianie tych cech charakterystycznych dla obecnych czasów, które uznane zostały za kluczowe. Wszystkie jednak uwzględniają czynnik zmiany.

Kwestii ponowoczesności nie da się rozpatrywać się bez odniesienia do ludzi, którzy ją tworzą. To właśnie człowiek kształtuje współczesną rzeczywistość, tak samo jak ona oddziałuje na niego. Dlatego też obecne społeczeństwo charakteryzuje się ogromną złożonością i zróżnicowaniem. Pojawia się w nim niezliczona liczba sposobów bycia i stylów egzystencji, co skłania także do uznawania odmiennych wartości. Pragnąc zapoznać się ze zdaniem respondentów dotyczącym tej problematyki, zadano im pytanie, w jaki sposób można określić współczesne społeczeństwo. Chodziło o to, by wskazać stopień, w jakim reprezentuje ono podane cechy. W celu ich wyodrębnienia, posłużono się zbiorem ukierunkowań społeczeństwa zaproponowanym przez Agnieszkę Cybal-Michalską (2006).

Analiza odpowiedzi udzielonych na to pytanie ukazuje, że młodzież bardzo często przejawia niezdecydowanie, zaznaczając odpowiedź „nie wiem”. Fakt ten stanowi zjawisko bardzo niepokojące, ponieważ młodzi ludzie zazwyczaj przejawiają światopogląd mieszczący się w ściśle określonych granicach, który relatywi- 
zuje się dopiero w progu dorosłości. Okazuje się również, że we wszystkich przypadkach wartości procentowe wskazują na zdecydowaną przewagę odpowiedzi potwierdzających występowanie podanych ukierunkowań nad tymi, które zaprzeczają ich istnieniu. Badani uważają, że w najwyższym stopniu uwidacznia się orientacja społeczeństwa na konsumpcję, wyrażająca się w dążeniu ludzi do zdobywania coraz większej ilości dóbr („zdecydowanie zgadzam się” - 28,3\%, „raczej zgadzam się” $31,8 \%$ ). Sytuacja taka świadczy o tym, że jest to cecha najbardziej charakterystyczna dla wielu współczesnych ludzi. W dobie nieograniczonych możliwości posiadania każda jednostka pragnie mieć coś swojego, co przynależy tylko do niej. Często nagromadzone przedmioty warunkują jej poczucie własnej wartości. Brak pewnych rzeczy oraz świadomość, że inni cieszą się z tego, iż są ich właścicielami, sprawia, że czujemy się gorsi, nic nieznaczący, a nawet niepotrzebni. Największy paradoks takiej tendencji polega na tym, że zależy nam na tym, by tylko zdobyć taki obiekt, a nie zadowalać się jego praktycznym zastosowaniem. Jedyną barierę w jego nabyciu stanowi brak odpowiednich funduszy. Dlatego też majętność staje się kolejnym czynnikiem wpływającym na prestiż współczesnego obywatela. Młodzież, prawdopodobnie, dostrzega takie zamiłowanie nie tylko w swoim otoczeniu, ale również u siebie, i uświadamia sobie „skłonności do czynienia z poczynań konsumpcyjnych najlepszego sposobu zaspokajania wszystkich innych potrzeb, a często także ostatecznego celu działań” (Bauman, 2011: 108).

Kolejną, również często zauważaną cechą współczesnego społeczeństwa jest orientacja na media („zdecydowanie zgadzam się” - 25,4\%, „raczej się zgadzam” 28,9\%). Oznacza to, że środki masowego przekazu pełnią w nim bardzo znaczącą rolę. Stanowią nie tylko ważny środek komunikacji, ale również przyczyniają się do kształtowania obrazu rzeczywistości poprzez przekazywanie różnorodnych informacji na jej temat. Niestety, nie zawsze są one wiarygodne, ponieważ niejednokrotnie pozostają wyrwane $\mathrm{z}$ kontekstu, w związku z czym ich interpretacja dokonywana na innych obszarach niż te, w których miały miejsce, nie zawsze jest zgodna z prawdą. Należy także zauważyć, że bez mediów wiele osiągnięć dokonanych przez ludzi nie miałoby miejsca. Funkcjonowanie współczesnego świata opiera się w głównej mierze na środkach masowego przekazu, dlatego stanowią one jego nieodłączny element i mimo zagrożeń, które ze sobą niosą, przyczyniają się do jego rozwoju i podnoszenia jakości życia.

Orientację społeczeństwa na wiedzę dostrzega ponad połowa respondentów („zdecydowanie się zgadzam” - 17,4\%, „raczej się zgadzam” - 33,5\%), jednak okazuje się, że w tym przypadku wysoki jest także odsetek osób, które raczej nie zga- 
dzają się z tą prawidłowością - 20,8\%. Posiadanie jak największej ilości wiedzy od zawsze było pragnieniem człowieka. Dzięki niej mógł on poznawać prawdę oraz rozumieć otaczającą go rzeczywistość. Obecnie jednak jednostka skupia się nie tylko na wyjaśnianiu pewnych prawidłowości, ale przede wszystkim na zdobywaniu coraz większej liczby informacji, które zyskują ogromną wartość. Niestety, mnożą się one z minuty na minutę, dlatego też bardzo szybko się dezaktualizują, $\mathrm{w}$ związku z czym jednostka pozostaje zmuszona do rozwinięcia $\mathrm{w}$ sobie zdolności do ich odpowiedniej selekcji. Czasami jednak dostęp do określonej wiedzy w danym momencie może okazać się bezcenny i przynieść człowiekowi ogromne korzyści. Młodzież, zgadzając się z istnieniem ukierunkowania społeczeństwa na zdobywanie informacji, zdaje sobie sprawę z istnienia opisanych wyżej właściwości.

Osoby, które zauważają, że obecnie dominuje tendencja dążenia do dostosowywania się do istniejących warunków życia i przewidywania nowych trendów („zdecydowanie się zgadzam” - 9,8\%, „raczej się zgadzam” - 39,4\%), potwierdzają pojawienie się orientacji współczesnych zbiorowości na antycypację. W ten sposób prezentują oni swoją świadomość dotyczącą tego, że aby przeżyć w jakichkolwiek warunkach, należy posiadać zdolność do adaptacji. W teraźniejszości jednak okazuje się ona cechą niewystarczająca, dlatego też musi zostać wsparta postawą otwartą na innowacje. Przewidywanie różnego rodzaju zmian i charakteryzowanie się umiejętnością do egzystowania w ich obrębie stanowi z pewnością cenny nabytek.

Młodzież dostrzega również skłonność ludzi do stawania się odpowiedzialnymi nie tylko za siebie, ale także za losy całego globu („zdecydowanie zgadzam się” - 15,6\%, „raczej zgadzam się” - 31,8\%). Prawidłowość ta dowodzi istnienia powinności troszczenia się o wspólnotę, myślenia o wszystkich. Świadczy to o tym, że pomimo powszechnych przekonań na temat przejawiania skłonności do egoizmu przez jednostki, prezentują one jednak dojrzałą postawę opierającą się na twierdzeniu, że niedomagania jednego z regionów świata mogą przyczynić się do zaburzenia funkcjonowania całości. Sytuacja ta nie przeszkadza jednak w prezentowaniu tendencji do zachowań ryzykownych, które zauważa dosyć spora część badanych („zdecydowanie zgadzam się” - 8,7\%, „raczej zgadzam się” - 30,6\%). Wynikają one z życia w warunkach nieustannej niepewności, które często wymagają podejmowania szybkich decyzji. Niestety, ich skutki pozostają praktycznie niemożliwe do przewidzenia z powodu ciągłych zmian.

Młodzi ludzie największe wahania dotyczące kwestii orientacji współczesnego społeczeństwa przejawiają w przypadku ukierunkowań zaproponowanych na globalną zmianę („nie mam zdania” - 46,8\%) oraz na odpowiedzialne uczestnictwo 
i współdziałanie („nie mam zdania” - 41,0\%). Oczywiście, w każdym z tych przypadków $1 / 3$ badanych potwierdza istnienie takich prawidłowości, jednak mimo to przejawia także wysoki poziom niezdecydowania. Zjawisko takie może być spowodowane małą wyrazistością pojawiania się zachowań wskazujących na funkcjonowanie niniejszych prawidłowości lub nieprzywiązywaniem do nich znaczenia przez młodzież. Powstawanie pewnych wspólnych sposobów myślenia i działania oraz tworzenie solidarności i więzi o charakterze ponadnarodowym jest ciągle jeszcze dostrzegane w małym stopniu oraz nie zostało rozpowszechnione.

Analiza wyników badań ze względu na wybraną zmienną, jaką stanowi miejsce zamieszkania, wykazuje, że w przypadku orientacji ponowoczesnych zbiorowości na globalną zmianę, jak i odpowiedzialność, mamy do czynienie ze wzrostem liczby odpowiedzi „raczej się zgadzam” wraz ze zwiększaniem się lokalizacji miejsca zamieszkania pod względem liczby mieszkańców. Prawidłowość ta jest wyraźnie widoczna $\mathrm{w}$ porównaniu odpowiedzi udzielanych przez uczniów pochodzących $\mathrm{z}$ dużych aglomeracji miejskich (orientacja na globalną zmianę - 36,7\%, orientacja na zbiorową odpowiedzialność - 42,9\%) oraz wsi (orientacja na globalną zmianę $27,7 \%$, orientacja na zbiorową odpowiedzialność - 25,7\%). Spowodowane jest to różnorodną specyfiką życia w obu środowiskach. Miasto charakteryzuje się przemijalnością oraz szybkim tempem funkcjonowania, w związku z czym zmiana stanowi dla niego podstawowy element istnienia. $Z$ kolei wieś odznacza się dużym spokojem i względną stabilizacją. Dlatego też tendencja do częstszego wskazywania orientacji na globalną zmianę przez młodzież miejską pozostaje absolutnie zrozumiała. Natomiast jej skłonność do dostrzegania zbiorowej odpowiedzialności można tłumaczyć większą umiejętnością przewidywania konsekwencji podejmowanych decyzji i oceniania ich znaczenia dla innych ludzi, która to zdolność kształtuje się w wyniku funkcjonowania w niestabilnych warunkach. Stwierdzenie takie potwierdza fakt, że młodzież wielkomiejska także częściej deklaruje swoją świadomość istnienia orientacji społeczeństwa na antycypację (miasto powyżej 100 tysięcy mieszkańców: „raczej się zgadzam” 42,9\%, „zdecydowanie się zgadzam” 10,2\%; wieś: „raczej się zgadzam” - 40,6\%, „zdecydowanie się zgadzam” - 6,9\%).

Agnieszka Cybal-Michalska zalicza się do niewielkiego grona badaczy, dla których stosunek młodych ludzi do ponowoczesności stał się jednym z głównych zainteresowań badawczych. Ukazuje ona, że większość młodzieży nie pozostaje obojętna na przemiany związane $z$ procesami globalizacyjnymi. Postawa taka wyraża się $\mathrm{w}$ poszukiwaniu, czerpanych głównie $\mathrm{z}$ mediów, informacji na temat mających miejsce przeobrażeń oraz $\mathrm{w}$ angażowaniu się w działalność różnych organizacji czy 
stowarzyszeń. Młodzi ludzie szczególną uwagą otaczają zjawiska związane z chorobami cywilizacyjnymi, głodem, terroryzmem, nieprzestrzeganiem praw człowieka, katastrofami ekologicznymi czy wojnami. Ciekawość odnosząca się do spraw globu odnajduje swoje odzwierciedlenie w konstruowaniu szeroko pojętej tożsamości, przybierającej charakter nie tylko narodowy, ale także europejski i globalny, przez co młodzi ludzie identyfikują się z określeniem „obywatel świata”. Respondenci przejawiają świadomość zarówno pewnych szans, jak i zagrożeń, jakie niesie ze sobą globalizacja. Do grona jej walorów zaliczają jednoczenie się krajów w sprawach ważnych dla świata, budowanie wzajemnych relacji politycznych, szybki przepływ informacji i możliwość swobodnego podróżowania. Natomiast za jej wady uznają zanikanie różnic kulturowych, homogenizację, nadmierny konsumpcjonizm.

Niniejsze wyniki badań, pomimo że związane są z oceną zjawiska globalizacji, potwierdzają wcześniejsze konkluzje dotyczące stosunku młodzieży do ponowoczesności. Wyrażane przez nią opinie i poglądy świadczą o prowadzeniu refleksji na temat współczesnego świata. To właśnie od młodych ludzi zależą przyszłe losy świata, a świadomość nadchodzących zmian stanowi podstawę $\mathrm{w}$ tworzeniu względnie trwałych i uogólnionych reprezentacji otoczenia. Okazuje się, że można wnioskować o stanie wiedzy badanych jednostek jedynie na postawie ich przekonań i opinii. Młodzież, posiadając zbiór przeświadczeń na temat otaczającej ją rzeczywistości, kształtuje w sobie odpowiedzialność za dokonujące się w niej przemiany.

Ponowoczesność stanowi również ciekawe zagadnienie dla analizujących ją teoretyków. Zbyszko Melosik w swoich rozważaniach wprowadza kategorię globalnego nastolatka (zob. Melosik, Szkudlarek, 2009), którego ambiwalentna tożsamość wypełniona jest nie przez wartości narodowe, ale ideały konsumpcyjne, kształtowane przez homogeniczną kulturę ogólnoświatową. Nastolatek ów posiada zdolność przystosowania się do funkcjonowania w każdym miejscu na świecie, w którym dominuje kultura globalna (zob. Melosik, 2011). Jednostki takie są bardzo pragmatyczne, łatwo nawiązują kontakty z innymi i tolerują odmienność. Żyją w bardzo szybkim tempie, podążając za duchem panujących trendów, propagowanych przez media, $\mathrm{z}$ których wybierają sposoby zachowań odpowiadające reprezentowanemu przez niech stylowi życia.

Ważne zagadnienie $\mathrm{w}$ obszarze analizy ponowoczesności stanowi również kwestia przyszłości teraźniejszego świata. Nawet młodzi ludzie posiadają świadomość tego, że kiedyś był on „inny”, obserwują także, jak przedstawia się obecnie, 
i najczęściej oceniają go w kategoriach negatywnych. Dlatego też warto zastanowić się nad tym, w jakim kierunku zmierza świat. W tym celu poproszono respondentów o wskazanie jednego $\mathrm{z}$ trzech wariantów odpowiedzi dotyczących niniejszej tematyki.

Młodzi ludzie najczęściej wybierali stwierdzenie określające współczesną rzeczywistość jako zmierzającą ku zagładzie i samozatraceniu (43,9\%). Oznacza to, że badani nie wróżą dobrze środowisku swojego życia i dostrzegają jego skłonność do autodestrukcji. W związku z tym, że jedynym stabilnym elementem współczesności staje się jej zmienność - nie ma ona żadnego punktu zaczepienia. Sytuacja taka przyczynia się do poczucia zagubienia jednostek w niej funkcjonujących, a w konsekwencji do ich dezorientacji. Młodzi ludzie, wybierając ten wariat odpowiedzi, pokazują, że mają świadomość istnienia takiego stanu rzeczy oraz wyrażają swój niepokój o losy świata, który funkcjonując w oparciu o swoje obecne założenia, nie pozwala na antycypację jednoznacznej wizji przyszłości.

Stosunkowo liczna część badanych prezentuje bardziej optymistyczne stanowisko w kwestii przyszłości obecnego globu - 28,3\% ankietowanych opowiada się za wersją utrzymującą, że ludzkość koncentruje się na przezwyciężaniu istniejącego przesilenia, by w jego następstwie zbudować rzeczywistość o lepszej jakości. Współczesna rzeczywistość często jest określana mianem pełnej kryzysów, których poszukuje się na płaszczyźnie gospodarczej, ekonomicznej, mentalnościowej i egzystencjalnej. Mogą one prowadzić do upadku lub przyczynić się do rekonstrukcji i w efekcie do powstania nowego i bardziej doskonałego świata. Adolescenci wybierający tę perspektywę podkreślają, że pojawiające się trudności i problemy, z jakimi mamy obecnie do czynienia, stanowią zjawisko normalne i są swoistą próbą poszukiwania właściwej drogi.

Trzeci wariant odpowiedzi, który został wskazany przez 26,0\% badanych, jest formą wyrażenia pozytywnego stosunku do obecnych czasów poprzez dostrzeżenie nieograniczonych szans, które oferują, oraz przekonania o możliwości dokonania jeszcze większego postępu w przyszłości. Najrzadsze wybieranie tego stwierdzenia świadczy o tym, że takie wyobrażenie świata nie wydaje się adolescentom zbyt realne. Grupa, która opowiada się za taką wersją, uważa obecną rzeczywistość za bardzo atrakcyjną i oferującą różnorodne możliwości, które przyczyniają się do podnoszenia jakości życia.

Osoby, które podjęły się próby samodzielnego stworzenia swojej wizji przyszłości, przedstawiają ją jako dążącą do zatracenia się w trwającym kryzysie, w którym nie dopatrują się oni szansy na zmianę, ale źródła upadku czy nawet końca świata. 
Z kolei niecały procent badanych opowiedział się za stanowiskiem, że rzeczywistość na zawsze pozostanie taka sama i nie ulegnie żadnym przeobrażeniom. Wypowiedzi te można zaliczyć do grona negatywnych wersji mających nastąpić wydarzeń.

Niniejsze badania pozwalają na stworzenie bardzo złożonego obrazu młodzieży jako jednostek troszczących się o kondycję współczesnego świata i dostrzegających jego niedoskonałości. Rzeczywistość wydaje się mało przychylna dla osób młodych. Muszą się one borykać z licznymi problemami. Ciągłe przeobrażenia gospodarcze stają się przyczyną „rozchwiania norm moralnych i postrzegania systemu normatywnego jako społecznie niepewnego" (Kluz, 2005: 13). Może to prowadzić do zagubienia i niemożliwości skrystalizowania swojej tożsamości oraz wypracowania hierarchii wartości. Rozwijająca się kultura konsumpcjonizmu zmusza niejako do przyjęcia swoich zasad funkcjonowania, mimo że niekoniecznie musi cieszyć się ona uznaniem młodych jednostek (Kowalska, 2005: 17-19). Z jednej strony, są one obciążone odnajdywaniem siebie i kształtowaniem swojego losu, z drugiej zaś muszą współgrać z życiem świata (Makaś, 2010: 197). Zostają zobowiązane do wykazywania się krytycyzmem myślenia, spontanicznością, twórczością, a jednocześnie skutecznością działania (Makaś, 2010: 201-202). Co więcej, cechy te nie mają być tylko przywilejem młodości, ale na jednostkach ciąży obowiązek ich utrzymania przez całe życie. Wszelkie te umiejętności młodzi ludzie muszą pozyskać samodzielnie, ponieważ ich rodzice i wcześniejsze generacje nie opanowały ich w tak wysokim stopniu, jak jest to wymagane, w związku z czym nie są w stanie nauczyć ich swoich dzieci. Ponowoczesność nie stanowi płaszczyzny, w której łatwo żyć, jednak pomimo swoich wad, niesie ze sobą bardzo wiele możliwości i szans dla rozwoju człowieka. Dzięki prawu do decydowania o własnym losie, każdy posiada zdolność do samodzielnego kreowania i realizowania wizji przyszłości.

Młodzież, zmuszona do funkcjonowania w zastanej rzeczywistości, stara się odnaleźć w niej swoje miejsce po to, by móc oddziaływać na wydarzenia istotne z punktu widzenia ludzkości i zapobiec katastrofie samozagłady, która stanowi jedno z prognozowanych wyobrażeń przyszłości. Kształtowanie swojego światopoglądu otaczane jest bardzo głęboką refleksją, co świadczy o wysokim poziomie odpowiedzialności wśród młodych ludzi. Bardzo dobrze rozwinięte umiejętności adaptacyjne pozwalają na kreowanie względnie stabilnego obrazu własnego Ja, co z powodzeniem można uznać na największy sukces rozwojowy współczesnych nastolatków. 


\section{Literatura}

Bakiera L. (2009). Czy dorastanie musi być trudne? Warszawa.

Baudrillard J. (2006). Społeczeństwo konsumpcyjne. Jego mity i struktury, przeł. S. Królak. Warszawa.

Bauman Z. (1991). Socjologiczna teoria postmoderny. [W:] Postmodernizm w perspektywie filozoficzno-kulturoznawczej. Red. A. Zeidler-Janiszewska. Warszawa, s. 7-25.

Bauman Z. (1993). Ponowoczesne wzory osobowe. „Studia Socjologiczne”, nr 2(19), s. 7-31.

Bauman Z. (2000). Ponowoczesność jako źródło cierpień. Warszawa.

Bauman Z. (2006). Płynna nowoczesność, przeł. T. Kunz. Kraków.

Bauman Z. (2007). Płynne życie, przeł. T. Kunz. Kraków.

Bauman Z. (2011). 44 listy ze świata płynnej nowoczesności, przeł. T. Kunz. Kraków.

Beck U. (2002). Społeczeństwo ryzyka. W drodze do innej nowoczesności, przeł. S. Cieśla. Warszawa.

Bell D. (1999). The Coming of Post-Industrial Society: A Venture in Social Forecasting, New York.

Benjamin R.B. (1997) Dżihad contra McŚwiat, przeł. H. Jankowska. Warszawa.

Castells M. (2007). Społeczeństwo sieci, przeł. M. Maroda. Warszawa.

Cybal-Michalska A. (2006). Tożsamość młodzieży w perspektywie globalnego świata. Studium socjopedagogiczne. Poznań.

Dziamski G. (1995). Ponowoczesna świadomość estetyczna. [W:] Trudna ponowoczesność. Rozmowy z Zygmuntem Baumanem, cz. I. Red. A. Zeidler-Janiszewska. Poznań, s. 147-160.

Frindt A. (2005). Czy warto być dorosłym? Społeczno-kulturowe uwarunkowania pojęcia dorosłości w świadomości młodzieży wielkomiejskiej. Warszawa.

Giddens A. (2008). Konsekwencje nowoczesności, przeł. E. Klekot. Kraków.

Havighurst R.J. (1981). Developmental Tasks nad Education. New York - London.

Kargulowa A. (2004). O teorii i praktyce poradnictwa. Odmiany poradoznawczego dyskursu. Warszawa.

Kluz T. (2005). Problemy wieku adolescencji w okresie zmian społecznych. „Wychowanie na Co Dzień”, nr $1 / 2$, s. 13-19.

Kosyrz Z. (2012). Oblicza tożsamości. Warszawa.

Kowalski M. (2005). Wokół triady: młodzież - konsumpcja - wychowanie (refleksje). „Wychowanie na Co Dzień", nr 1/2, s. 17-19.

Kwieciński Z. (2004). Przyszłość wychowania w świecie bez przyszłości „Horyzonty Wychowania”, r. 33.

Kwiek M. (2000). Tożsamość narodowa - państwo narodowe - demokracja. Filozoficzne i polityczne wyzwania epoki globalizacji. [W:] Przezwyciężanie barier w integrującej się Europie. Red. Z. Drozdowicz, Z.W. Puślecki. Poznań, s. 73-80.

Makaś A. (2010). Młodzież w czasach ryzyka. [W:] Młodzież w XXI wieku. Źródła wzrostu i kryzysów. Red. E. Jackowska, B. Kromolicka. Szczecin, s. 197-204.

Maslow A. (1987). Motivation and Personality. New York.

Matysek M. (2007). Ponowoczesność - porzucony projekt, czyli o uplynnianiu świata nowoczesnego. Spojrzenie Zygmunta Baumana. [W:] Nowoczesność po ponowoczesności. Red. G. Dziamski. Poznań, s. 19-38.

Mayor F. (2001). Przyszłość świata. Warszawa.

McLuhan M. (1962). The Gutenberg Galaxy. Toronto.

Mead M. (2000). Kultura i tożsamość. Studium dystansu międzypokoleniowego, przeł. J. Hołówka. Warszawa. 
Melosik Z. (1998). Wychowanie obywatelskie: nowoczesność, ponowoczesność. [W:] Wychowanie obywatelskie. Studium teoretyczne, porównawcze i empiryczne. Red. Z. Melosik, K. Przyszczypkowski. Toruń - Poznań, s. 45-51.

Melosik Z. (2001). Młodzież i styl życia: paradoksy pop-tożsamości. [W:] Młodzież. Styl życia i zdrowie, konteksty i kontrowersje. Red. Z. Melosik. Poznań, s. 11-57.

Melosik Z. (2010). Tożsamość, ciało i władza w kulturze instant. Kraków.

Melosik Z., Szkudlarek T. (2009). Kultura, tożsamość i edukacja: migotanie znaczeń. Kraków.

Naisbitt J. (2003). High tech, high touch: technologia a poszukiwanie sensu, przeł. A. Unterschuetz. Poznań.

Obuchowska I. (1983). Okres dorastania. Warszawa.

Obuchowski K. (2000). Człowiek intencjonalny, czyli o tym, jak być sobą. Poznań.

Okoń W. (2007). Nowy słownik pedagogiczny. Warszawa.

Oleniacz M. (2005). Przeżywanie młodości. Obraz fenomenu w badaniach biograficznych. Kraków.

Oleszkowicz A. (1995). Kryzys młodzieńczy - istota i przebieg, na podstawie wybranych psychologicznych koncepcji rozwoju człowieka i badań empirycznych. Wrocław.

Oleszkowicz A. (2006). Bunt młodzieńczy. Uwarunkowania, formy, skutki. Warszawa.

Popper K., Społeczeństwo otwarte i jego wrogowie, t. I: Urok Platona, przeł. A. Chmielewski. Warszawa. Prigogine I. (1994). Przedmowa. „La Nouvelle Page”, du Rocher/UNESCO.

Reykowski J. (1958). Światopogląd jako fakt psychologiczny. „Euhemer”, nr 5, s. 3-16.

Smart B. (1998). Postmodernizm, przeł. M. Wasilewski. Poznań.

Świda-Ziemba H. (2005). Młodzi w nowym świecie. Kraków.

Toffler A. (2001). Trzecia fala, przeł. E. Woydyłło. Warszawa.

Turner J.S., Helms D.B. red. (1999). Rozwój człowieka, przeł. S. Lis [et al.]. Warszawa.

Vasta R., Haith M.M., Miller S.A. red. (1995). Psychologia dziecka, przeł. M. Babiuch [et al.]. Warszawa.

Zeidler-Janiszewska A. red. (1995). Trudna ponowoczesność. Rozmowy z Zygmuntem Baumanem, cz. I. Poznań.

\section{Image of Postmodern World from the Perspective of Contemporary Youth}

\section{Summary}

The condition of the modern human being is not free from the influence of the postmodern reality, which is unpredictable, ambivalent and has many meanings. The constant change is not without influence over the process of forming ones identity, which is subject to changing value systems and achieving stability is very difficult. This forces the development of an adaptation ability and flexibility. Because of that the subject is obliged to acquire those abilities and adapt a pro-development orientation towards its own future. The ability to constantly update ones skills is a key factor to achieving success in life.

This discourse doesn't omit questions about modern teenagers, who are forced to live in modern day world. People getting through their adolescence are trying to find their place in life and to develop 
their own views about the world. Post modernity, even though it carries a lot of dangers, is also a chance for young people to develop their own value system.

A reflection about this and a wish to verify it was key to an empirical study. This study, based on which it was possible to reconstruct the reality of postmodern teenagers was conducted from December 2012 to January 2013 in five high schools in the Greater Poland and Kuyavian-Pomeranian districts. 173 students, aged 18 to 20, took part in it. Their age was chosen based on the fact that they should already have a relatively stable view of the world.

This study allows to create a very detailed view of modern youths seen as people caring about the condition of the modern world and conscious of its imperfections. Constant economical change is a reason for seeing it as a place that is very unstable and devoid of values. It may lead to inability to fully develop one's self and forming a stable value system. The growing culture of consumerism forces people to adapt to its rules even though they may not be highly valued by young people. On the one hand they are burdened with self-development and on the other they have to adapt to the reality of the modern world. They are forced to critical thinking, spontaneity, creativity but also efficiency. Furthermore those traits are not to be only a privilege of youth but they are to be kept for the entire life. All those abilities have to be attained independently because the generation of today's parents and the older generations did not develop them sufficiently and cannot pass them to their children. Post modernity is not an easy time to live in, but despite its faults it carries a great opportunity for selfdevelopment.

Today's youth forced to function in modern reality tries to find their place in it in order to influence events important for mankind to evade destruction which is one of the possible future scenarios. Developing of a value system is done with great reflection, which is a sign of a high level of responsibility. Very good adaptation skills allow to create a relatively stable sense of „I”, which can be called a great success of modern teenagers. 